The determ nants of bank net i nt er est margi ns: A panel evi dence from South Asi an count ri es

\begin{tabular}{|l|l|}
\hline 著者 & I sl am Shahi dul , N shi yama Shi n- I chi \\
\hline $\begin{array}{l}\text { j our nal or } \\
\text { publ i cat i on t i t l e }\end{array}$ & DSSR Di scussi on Paper s \\
\hline number & 32 \\
\hline page r ange & $1-39$ \\
\hline year & $2015-02$ \\
\hline URL & ht t p: //hdl . handl e. net /10097/65008 \\
\hline
\end{tabular}



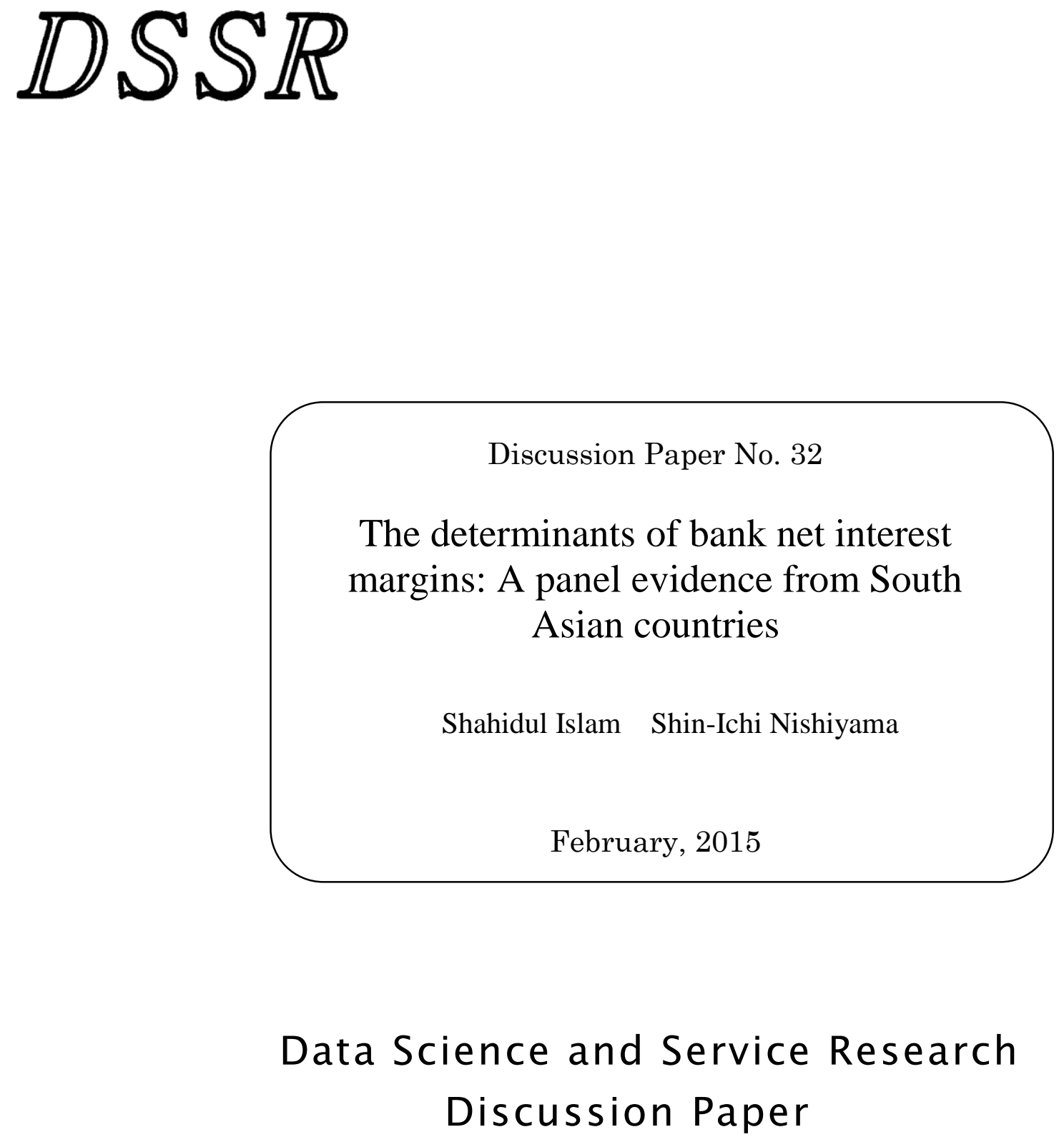

Center for Data Science and Service Research Graduate School of Economic and Management Tohoku University 27-1 Kawauchi, Aobaku Sendai 980-8576, JAPAN 


\title{
The determinants of bank net interest margins: A panel evidence from South Asian countries
}

\author{
Shahidul Islam ${ }^{\text {a, b, } 1}$, Shin-Ichi Nishiyama ${ }^{\text {a }}$ \\ ${ }^{a}$ Graduate School of Economics and Management, Tohoku University, Japan \\ ${ }^{b}$ Department of Banking and Insurance, University of Dhaka, Bangladesh
}

\begin{abstract}
:
This paper studies the determinants of net interest margins of banks (NIMs) in four South Asian countries (Bangladesh, India, Nepal and Pakistan) in the period 1997-2012 using panel data of 230 banks. The study is in line of Ho-Saunders (1981) dealership model and its later expansions but extended the model by adding new variable the relative size of the banks and also classifying the determinants of interest margins as bank specific, industry specific and macroeconomic specific variables. We found that liquidity and equity positions, required reserve and operating expenses to total asset ratios affect net interest margins positively while relative size of the banks, market power and economic growth affect inversely.
\end{abstract}

JEL classification: G21, C23

Key words: net interest margins, spread, non-performing loan

\section{Introduction}

Existence of net interest margins (NIMs) or spread is the fundamental factor of Banking as the Financial Intermediary business. Spread is the difference between the weighted average of yields on assets (interest revenue) and liabilities (interest expense) - also called the bankers' mark-up (Allen, 1988). However a very high or low and volatile spread can cause severe bank management problem and can create distrust among the stakeholders of the banking business. There may be a strong relationship between the higher spreads and higher default rate. Again from bankers' perspective, there may be trustworthy causes to charge higher margins as the

\footnotetext{
${ }^{1}$ Corresponding author. Graduate School of Economics and Management, 27-1 Kawauchi, Aoba-ku, Sendai 980-8576, Japan. Tel: +81- 080-4514-7262. E-mail: sizahid2000@gmail.com
} 
wealth maximizer candidate in the economy. From the societal perspective, the higher the interest margins, the lower will be the social welfare. So, regularly updating our knowledge on interest margin determinants is valuable for number of reasons including monitoring changing trends in bank efficiency through time and evaluating whether bank margins are providing effective price signals to market players (Hawtrey and Liang, 2008).

In line of the Ho and Saunders' (1981) dealership model of banking where the banks receive deposits funds at random intervals, and subsequently, utilize these funds to satisfy stochastically received loan request has been studied for many years by different scholars in extended formats. Allen's (1988) studies on portfolio effects on spreads and Saunders- Schumacher's (2000) considerations for regulatory components, a market structure component and a risk premium component to determine the net interest margins of bank are notable. Angbazo (1997) studied the dealership model in single stage, considering the credit risk and also interest rate risk. Maudos and Guevara (2004) extended the dealership model viewing banks as the firm considering the operating expenses explicitly into account.

Kunt and Huizinga (1999) found that a larger ratio of bank assets to gross domestic product and a lower market concentration ratio lead to lower margins, controlling for differences in the bank activity, leverage and the macroeconomic environment in their 80 cross-country sample study. Bernanke, Gertler and Gilchrist (BGG) (1999) in their dynamic general equilibrium model to clear the credit market frictions in business fluctuations and Gertler and Kiyotaki (2011) in their macroeconomic paper on financial intermediation and credit policy in business cycle analysis also discussed about the effect of net worth of banking firms and default probability and their impact on margin determination. 
In this paper, we tested the dealership model and its later extensions of bank interest margin determinants in case of four South Asian countries that is Bangladesh, India, Nepal and Pakistan, using fixed effect panel of 230 banks data for the period of 1997 to 2012. We viewed each country's banking sector in terms of a single representative agent and interested in margin determination on national basis. We studied the explanatory variables of interest margins classifying as bank specific, industry specific and macroeconomics specific and incorporated new bank specific variable the relative size of the bank which we found significantly and inversely affect net interest margins of banks. In our empirical model, we included 15 deterministic variables which seems a populous model of interest margin determinants in terms of number of variables. Selection of our sample was also notable on the ground that most of our sample countries (Bangladesh, India and Pakistan) were under the rule of British colony for around two hundred years. We got the opportunity to study those countries' banking systems all -together considering likely regulatory, social and economic environments. The similarities of the countries gave us opportunity to test our theoretical model empirically using fixed effect panel regression. We also ran country-wise fixed effect panel regression and presented in the paper along the base line regression result. In the near past we found similar studies ${ }^{2}$ on developed and developing countries of USA, Europe, Australia and Latin America but in case of South Asia, this study is a unique addition to the literature of the determinants of bank net interest margins.

The rest of the paper has been organized as follows: in section 2, we presented relevant literature on the determinants of net interest margins. In section 3 the empirical approach of our study and

\footnotetext{
${ }^{2}$ Kunt and Huizinga(1999) studied 80 developed and developing countries, Saunders and Schumacher's (2000) studies included USA and six EU countries, Maudos and Guevara (2004) studied 5 European countries. Also Afanisieff (2002) and Williams (2007) studied determinants of net interest margins on Brazilian and Australian banks respectively among others.
} 
in section 4 the sample description has been outlined. In section 5 the result and finally in section 6 we presented the conclusion and policy implications of our study.

\section{The literature on determinants of net interest margins}

Starting point of bank net interest margins determinants can be attributed to the dealership model of Ho and Saunders (1981) as an extension of the hedging hypothesis and the expected utility approach. In their landmark initiative, they proposed the two stage model of interest margin determination. In stage one; they argued the existence of 'pure spread' as the price of providing immediacy of services in face of the uncertainty generated by asynchronous deposit supplies and loan demands. In stage two; they attempted to measure the amount of pure spread by considering number of imperfections and regulatory restrictions. According to the model, pure spread is the difference between the bank lending rate $\left(P_{L}\right)$ and the deposit rate $\left(P_{D}\right)$. As there exist transaction uncertainty, banks set their interest rates as a margin relative to the interest rate of the money market $(p)$. These happens as,

$P_{D}=p-a$

$P_{L}=p+b$

Where $a$ and $b$ are the margins for the provision of immediacy services. Thus, as the risk averse, utility maximizer, bank’s pure spread $(S)$ could be determined as follows:

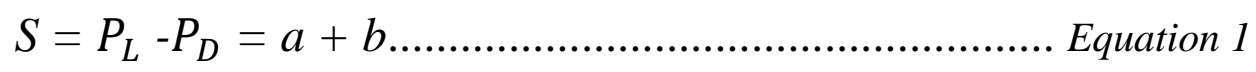

Lerner (1981) criticized the dealership model that it failed to recognize the bank as a firm having a certain production function associated with provision of the intermediation services. The 
presence of cost inefficiencies associated with the production process across banks can have a distortionary effect on the margin. The extension of the basic dealership model by Maudos and Guevara (2004) responded to this criticism by explicitly incorporating the role of operating costs and providing a detailed description of the link between riskiness and the margin in their one stage model of interest margin determinants which covered the data of 5 European countries to prove the model empirically.

Allen (1988) expanded the dealership model from a structure with one kind of loan and deposit to loans and deposits with many maturities that is the 'portfolio effect' apparent to margin determination. Angbazo (1997) studied the net interest margins of commercial banks reflect both default and interest rate risk premia. The study also showed that banks with more risky loans and higher interest rate risk exposure would select loan and deposit rates to achieve higher net interest margins and cross sectional differences in interest rate risk and liquidity risk are related to differences in off-balance sheet exposure.

Saunders and Schumacher (2000) conducted an international study on USA and European banks for the net interest margin determination for 1988-1995 period and found that implicit interest payments, opportunity cost, capital to asset ratio, market power and interest rate volatility affect net interest margins positively but they omitted any proxy variable for risk aversion and size of transaction in their model. Afanasieff et al. (2002) used a panel regression of 142 Brazilian banks and found that size of bank, opportunity cost and operating cost are positively related to interest margins but a set of macroeconomic variables such as the market interest rate, the volatility of market interest rate, inflation rate and output growth heavily affect margins as well. 
Valverde and Fernandez (2007) applied Ho and Saunders dealership model to a multi-output framework and showed that the relationship between bank margins and market power varies significantly across bank specializations. They conducted empirical studies for a sample of 19,322 European banks from Germany, Spain, France, the Netherlands, Italy, the UK and Sweden and found that market power increases as output becomes more diversified towards nontraditional activities. Hawtrey and Liang (2008) studied the determinants of bank interest margins using panel data covering the banking sector of fourteen OECD countries and found that national banking industry interest margins are influenced by market power, operational cost, risk aversion, interest rate volatility, credit risk, volume of loans, implicit interest payments and also quality of management. With a particular emphasis on the bank ownership structure, Fungacova and Poghosyan (2011) conducted empirical studies using panel data on the interest margin determinants in the Russian banking. They found that the impact of a number of commonly used determinants such as market structure, credit risk, liquidity risk and size of operations differs across ownership structure of banks but influence of operational cost and risk aversion are homogeneous. Among others, Tarus et al. (2012) studied the determinants of net interest margins of commercial banks in Kenya using pooled and fixed effect panel covering the period of 20002009. They found that operating expenses, credit risk and inflation are positively and market concentration and economic growth are negatively related to the net interest margins.

In the literature of the determinants of interest margins of banks, we also recognize the studies of Bernanke, Gertler and Gilchrist (BGG, 1999). Another seminal study was conducted by Gertler and Kiyotaki (2011) where their macroeconomic viewpoint on the interest margin is that so called risk aversion or the net-worth position of banks negatively and the default risk positively influences the net interest margins of banks. 
We get the motivation for our present study by the inconclusive nature of the empirical literature of the determinants of net interest margins of banks. We want to focus on the determinants of net interest margins by adding new variable the relative size of banks and also incorporating the explanatory variables both microeconomic and macroeconomic in the past literature in our contemporary cross-country study. A prior cross country study was conducted by Kunt and Huizinga (1999) using global 80 countries’ data over the period 1988 to 1995, however their particular concern was exogenous influences such as macroeconomic indicators, tax rates and the degree of international ownership, all of which found significantly related to interest margins. Complementing their works, our study results, reported here focus on both microeconomic and macroeconomic determinants of the net interest margins of banks.

\section{Empirical Approach}

\subsection{Econometric Model}

We used the fixed effect panel estimator to evaluate the impact of various determinants of bank net interest margins (NIMs) in the South Asian countries. The fixed effect model is:

$$
\begin{aligned}
Y_{i t} & =\alpha+\beta X_{i t}+u_{i}+\varepsilon_{i t} \\
& =\alpha_{i}+\beta X_{i t}+\varepsilon_{i t}
\end{aligned}
$$

Where, $\alpha_{i}=\alpha+u_{i}$ and $\varepsilon_{i t}$ is independently and identically distributed (i.i.d).

Our model to be estimated is of the following linear form:

$$
\begin{gathered}
\text { NIMit }=\text { F [Bank Specific Factors (BSF), Industry Specific Factors (ISF), Macroeconomic } \\
\text { Specific Factors (MSF)] }
\end{gathered}
$$

Or, NIMit $=$ F[BSFit (.), ISFit (.), MSFt(.)]

So, the general specification model (equation 2) can be re-written as follows: 


$$
N I M_{i t}=C+\sum_{j=0}^{J} \beta_{j} X_{i t}^{j}+\sum_{l=0}^{L} \beta_{l} X_{i t}^{l}+\sum_{m=0}^{M} \beta_{m} X_{i t}^{m}+\sum_{d=0}^{D} \gamma_{d} Z_{t}^{d}+u_{i}+\varepsilon_{i t}
$$

Equation 3

Or, for fixed effect specification, we can rewrite the equation 3 as follows:

$$
N I M_{i t}=\mathrm{C}+\sum_{j=0}^{J} \beta_{j} X_{i t}^{j}+\sum_{l=0}^{L} \beta_{l} X_{i t}^{l}+\sum_{m=0}^{M} \beta_{m} X_{i t}^{m}+\sum_{d=0}^{D} \gamma_{d} Z_{t}^{d}+\varepsilon_{i t}
$$

Equation 4

Where, $N I M_{i t}$ is the net interest margin of bank $i$ at time $t$. The superscripts $j, l$ and $m$ of Xit, denote the bank-specific, industry specific and macroeconomic specific variables respectively. Whereas, $Z$ is unobserved variable but correlated with $X . Z$ can be interpreted as an intercept of unobserved effect of observation $i$ and unobserved time specific effects on the dependent variable can be captured by introducing time dummies so we did in our study as $\left(\boldsymbol{Z}_{\boldsymbol{t}}^{\boldsymbol{d}}\right)$. All other regulatory and country specific effects supposed to be included in the constant term (C).

\subsection{Variables}

The econometric model developed in the section 3.1 to determine the net interest margins of banks in the South Asian countries requires proxy variables to prove the model empirically. We have used 3 categories if explanatory variables namely (i) bank specific, (ii) industry specific and (iii) macroeconomic specific variables. In total we used 15 explanatory variables of which 11 are bank specific, 1 industry specific and 3 macroeconomic specific. Some of the variables have been considered to prove our initial hypotheses and some of them for the controlling purpose only. Additionally we used time dummies in our model to see the time variant influences (if any) to determine the net interest margins of banks. However the categorical variables have been proxied empirically as follows: 


\subsubsection{Dependent variable}

Net interest margins (NIM)

In our econometric model of determinants of net interest margins, net interest margins (NIM) is the dependent variable. We defined net interest margins of a bank as the difference between interest income and interest expense divided by total assets.

\subsubsection{Explanatory variables:}

(a) Firm specific explanatory variables

(i) Relative size of the bank

Relative size of the bank is used as the proxy variable of information asymmetry in our econometric model of determinants of net interest margins. We want to see how information asymmetry affects the net interest margins of banks. But it is hard to find the information asymmetry variables from the disclosed chapters of the bank information from their financial statements. Then we aimed to characterize banks as small and large (relative size) in terms of their holding of assets. We calculated the relative size of the bank as the ratios of total asset of bank $i$ to the total banking industry asset of the economy. Relative size of the bank in our model as explanatory variable, answers the question of whether the large banks are charging more or less in relation to the small banks or not. Our hypothesis is that, holding others remaining constant, the relative size of the bank affect the net interest margin inversely.

(ii) Non-performing loan (NPL)

Non-performing loan to total loan which actually the default risk of bank $i$ has been used as the explanatory variable in our model. Many of the past literature expressed this variable as credit 
risk or default risk and calculated differently. For example, Ho and Saunders (1981) used default premium (DPi) as the ratio of net loan chargeoffs to total earning assets in their two stage model of determining net interest margins of banks. Moudos and Guevara (2004) proxied credit risk as loans to total assets ratio. According to the Bank for International Settlements (BIS, 1999) loans are the largest and most obvious source of credit risk for most banks but we think this approach is too pessimistic to measure the credit risk for banks. However, this is natural for banks to charge additional on the initial margins on lending if the borrower's probability of being default is high. We expect ceterus paribas, a positive relationship between non-performing loan and the net interest margins.

(iii)Interaction between non-performing loan (NPL) and Standard deviation of short term interest rate (SDint)

This interaction variable has been used in our econometric model of determining the net interest margins of banks to see whether they are jointly affect the dependent variable or not. Use of this variable has been supported by the previous literature for example Maudos and Guevara (2004), Hawtrey and Liang (2008) among others.

(iv)Liquid asset to total asset ratio

Following Angbazo (1997), we used the variable liquid asset but calculated differently for our modeling. Angbazo (1997) used liquid asset to liabilities to proxy for the liquidity risk as the determinant of net interest margins. However, in our model, liquid asset (extracted from the Bank Scope database as the total earning assets) to total asset is a proxy for the liquidity position of the bank. We argue that banks are not only provider of liquidity on demand to the liability side but also on the asset side in the form of providing loan commitments and so on. Banks whose 
liquidity position is better than others may charge extra margins on the loans they provide. For this, a positive sign is expected.

\section{(v) Equity to total asset ratio}

The variable measures the capitalization of a bank considering the regulatory requirements regarding the minimum equity holdings. Following McShane and Sharpe (1985), we also used equity to total asset ratio as the proxy of degree of risk aversion of banks. Among others, Saunders and Schumacher (2000), Maudos and Guevara (2004) used the variable in the same way but Hawtrey and Liang (2008) used different approach to calculate the risk averseness of the banks by dividing securities plus other assets by volume of loans.

Regarding the relationship between equity to total asset ratio and the net interest margins of banks, we found contrast literature in the past. Macroeconomic stream like Gertler and Kiyotaki (2011) framework argued that the rise in net worth (equity) relative to the capital stock reduces the expected default probability, everything else equal. The underlying economics of that proposition is that banks can charge lower margins where default probability is lower.

On the other hand, mainstream banking and finance literature expect positive sign arguing that customers are willing to bear (pay for) bank regulatory taxes in return for the positive externality related to bank monitoring. That is 'banks are special' and customers are willing to pay for that specialness (as cited by Saunders and Schumacher, 2000). To address the systematic risk and other regulatory reasons, banks maintain certain equity level. So, everything remains constant, the risk averse bank tends to charge more as the interest margins. Hence, we expect the positive relationship between equity to total asset ratio and the net interest margin of bank. 
(vi)Total loan to total deposit ratio

Differences in the standard deviations of deposit strength and the loan strength (long run relationship) explain the heterogeneity in bank’s price setting behavior (Gambacorta, 2008). In our model of determinants of net interest margins of banks, we applied this total loan to total deposit ratio as the explanatory variable to see whether the funding strength (how much of the total loan have been financed through deposit and other sources of funding) has any significant deterministic power to banks’ price setting or in other words net interest margins. In this study, we expect positive sign between total loan to total deposit ratio and the net interest margin of bank.

(vii) $\quad \log (\operatorname{loan})$

Ho and Saunders (1981) showed that size of transaction and banks' interest margins are positively related. Maudos and Guevara (2004) also stated that banks apply large margins on sizable volume of loans. But the reality is different. We see big-loan-customers enjoy special discounted rate (prime rate) on their borrowings. Also, banks enjoy the economies of scale benefit of processing and maintenance cost of big loans which reduces banks operating cost to revenue. As Hawtrey and Liang (2008) expected negative relationship between log (loan) and interest margins arguing that increased volume of loans should result in a reduction of unit costs, which achieves economies of scale and results in narrower margins. Again, McShane and Sharpe (1985) assumed that size of the transaction is invariant across trading banks and time. We used the logarithm of total loan as the proxy for size of operation or so called scale effect in our model and expect positive relationship between log (loan) and net interest margin of a bank. 
Modern banking and their services have been expanded in many folds so their sources of income and heads of expenditures. A bank incurs cost of deposits as the largest volume of interest expenses and the interest income on loans as the largest volume of interest income. Other than the interest income that is the non-interest income may include service and penalty charges, capital gain on assets sales, property leasing etc. On the other hand, expenses not included in the cost of deposits like almost all operating and overhead costs will be included as non-interest expenses.

Net non-interest income as the proxy for implicit interest payment and an explanatory variable to determine the net interest margin of banks can be found in many previous literature. Among others, Ho and Saunders (1981), Angbazo (1997), Saunders and Schumacher (2000) calculated this as the net non-interest income (non-interest expense less non-interest revenue) divided by earning assets whether Maudos and Guevara (2004) expressed the same as the percentage of total assets. We followed the later approach and expected that, everything else remaining constant, an increase in the net non-interest income will affect a bank's net interest margin positively.

(ix)Required reserve to total asset ratio

Portion of deposits that a bank must hold but cannot lend out is the required reserve. This is one of the regulatory variables of central banks to conduct monetary policy. Although, this safeguards the depositors against sudden run out of banks but for banks, holding every penny from the deposit amount reduces the loanable funds so as reduce the probability of earning more interest income on loans or from investing in the financial markets. The larger the volume of required reserve, the greater will be the opportunity cost. In our econometric model of 
determinants of net interest margins of banks, we used cash and due from banks from bank scope database as the proxy measure for required reserve. Our hypothesis is, holding other things remaining constant, the larger the volume of required reserve of a bank, the more will be the net interest margin.

(x) Operating expenses to total assets ratio

Operating expenses of a bank includes non-interest expenses like overhead and administrative cost, maintenance of properties and others. Controlling for these costs promotes efficiency of the bank and enhances the competitiveness as well. Among others, Kunt et. all. (1999), Maudos and Guevara (2004), Hawtrey and Liang (2008) studied the effect of overhead expenses on determining interest margins of banks. We also employed the operating expenses to total asset ratio in our model to see how this variable affect the net interest margins of a bank. Principally, if a bank's unit operating expenses is relatively higher (less efficient), that bank will try to compensate that by charging additional on the regular margins. So, a positive sign has been expected.

(xi)Operating expenses to gross income ratio

Operating expenses to gross income ratio captures the bank management's efficiency showing the amount of expenses for every one dollar of income generated to the firm. According to Angbanzo (1997) as well as Maudos and Guevara (2004) the higher the quality of management of a bank, the higher the interest margins that will be imposed by the bank, on the ground that a high quality of administration implies a high yield and low cost composition of assets and liabilities. On the other hand Gischer and Juttner (2002) argued inverse relationship between the 
quality of management and the net interest margins of banks but failed to prove their hypothesis empirically. In our empirical model of determinants of net interest margins, our hypothesis is that bank may charge higher margins for their excellent service offered to the customers.

(b) Industry specific explanatory variable

(xii) Herfindahl index

We used the Herfindahl Index (HI) in our econometric model of determinants of net interest margins of banks to find out the relationship between market concentration and the net interest margins in South Asia. Herfindahl index has been defined as the sum of squares of individual bank asset shares in the total banking sector assets for a country. This is a common and widely used measure of market concentration where higher market concentration means lower competition and vice versa. Past literature has contrasting views regarding the relationship between market concentration and interest margins of banks. Most of the recent studies ${ }^{3}$ on the developed countries found positive sign coefficient for the variable. But Hesse (2007) and Fungacova and Poghosyan (2011) who studied Kenyan and Russian banking respectively found negative relationship between market structure and the net interest margins of banks. We expected positive relationship between the market concentration and net interest margins of banks supportive to the Ho and Saunders' (1981) proposition that, if a bank faces relatively inelastic demand and supply functions in the markets in which it operates, it may be able to exercise monopoly power by demanding a greater spread than it could get if banking markets were competitive.

\footnotetext{
${ }^{3}$ Angbanzo (1997), Saunders and Schumacher (2000), Maudos and Guevara (2004), Williams (2007) for reference.
} 
(c) Macroeconomics specific explanatory variables

(xiii) Standard deviation of short term interest rate (SDint)

Past literature used variety of measures to proxy for the volatility of interest rates and its impact on the net interest margins of banks, including rates on short term money market rates to medium and long term capital market rates. For our model of determinants of net interest margins of banks, we used the annualized standard deviation of monthly average of daily call money rates. Based on the monthly average of the daily call money rates, we have calculated the annual standard deviation. We also assumed that there will be positive impact of the SDint on the net interest margins of banks.

(xiv) Rate of inflation

Although there is no empirical consensus on the effects of inflation on interest margins, high inflation rates are generally associated with high interest rates and therefore, higher interest margins. Even if inflation is not anticipated by banks, in the short term interest rates may not reflect the increased inflation, but in the medium and long term, banks will adjust their interest rates to compensate for the inflation premium and will increase the interest margins (Tarus et al., 2012). Kunt et al. (1999) found a positive relationship between inflation and the net interest margins in their study with global evidences from 80 countries. On the other hand, Abreu and Mendes (2003) found inverse relationship between rate of inflation and net interest margins of banks on a cross country study of Portugal, Spain, France and Germany. Our hypothesis is rate of inflation affect net interest margins positively. 
(xv) Growth rate of gross domestic product (GDP)

Growth rate of GDP or economic growth rate of a country is important variable to influence the determinants of net interest margins of banks. Growth rate of GDP affect directly the demand and supply of deposits and loans and thus the banking activities. Kunt et al. (1999), Tarus et al. (2012) studied the importance of economic growth rate to determine bank interest margins and found inverse relationship. We also argue that economic growth brings prosperity to the economy. Investors find various scope of investment and create green fields for the banks for financing. Banks can do business in a relatively ease environment and thus may charge little as interest margins. Hence, our hypothesis is that growth rate of GDP significantly and negatively affects net interest margins of banks.

\section{Sample description:}

In our econometric model of the determinants of net interest margins of banks, we studied 230 banks of four countries in South Asia between 1997-2012 periods to test the model empirically. By countries, India represents 53\% banks in our total sample while Bangladesh, Nepal and Pakistan represent 14\%, $13 \%$ and $20 \%$ respectively. We defined banks as the financial intermediary who takes deposits and provide loans and advances in the ordinary courses of business. We excluded the data of Islamic banks from our sample as in India and Nepal there is no or very limited Islamic banking operation. For our analyses, we collected data from various sources. The dependent variable and the bank specific explanatory variables, we collected data from the Bureau Van Dijk’s Bank Scope database (Bank Scope 2013) using the universal model of banking database. We took the primary data set from the Bank Scope but calculated by our own to get the Herfindahl Index and Concentration Ratio (CR3) which we used as the industry 
specific explanatory variables in the baseline model and also to perform the robustness check. Finally, for macroeconomics specific variables, we collected data from two sources. We collected the data regarding interest rate volatility from the central banks websites of the respective countries included in our study. We took the monthly averages of the daily call money rates and later calculated the annual standard deviation at our own. From International Financial Statistics (IFS) database (IFS 2014), we collected yearly data of rate of inflation and the growth rate of gross domestic product (GDP).

Table- 1 in the following presents the summary statistics of the determinants of net interest margins. In South Asian countries, in our study period, average net interest margin was 2.98\% with 3.28\% standard deviation. Relative size of the bank was 3.21\% and the non performing loan rate was $8.1 \%$ on an average.

\section{<Table-1>}

Liquid asset to total asset ratio averaged $86.02 \%$ whereas equity to total asset ratio average was $11.58 \%$ with $13.36 \%$ standard deviation. Among others, average required reserve ratio was $5.64 \%$ and operating expense to total asset ratio was $2.98 \%$ on an average.

Average value of Herfindahl Index 0.1398 indicates the existence of sound competitive banking environment in the South Asian countries. Average rate of inflation was slightly more than $7 \%$ and South Asian nations grew about 6\% in our sample period.

Table-2 presents the average and standard deviation of net interest margins of South Asia from 1997 to 2012. Also figure-1 and figure-2 in the following present the average and standard deviation of net interest margins. From these table and figures we see over the period, in Pakistan 
average net interest margins was higher than the South Asian average while in Bangladesh that was lower. In 2003, Pakistani banks' earned on an average 5\% net interest margin that was the highest in our sample period and that was the lowest (0.5\%) for Bangladesh in the year 1997.

\section{$<$ Figure-1 $>$}

\section{$<$ Table-2}

From figure -2, we also observe the higher dispersion of net interest margins of banks in Pakistan and may be the lower in case of banks in Bangladesh over the sample period.

\section{$<$ Figure-2 $>$}

\section{Results:}

We used fixed effect ${ }^{4}$ model to capture the specific characteristics of each group, using the within-group estimator. We also introduced the time dummies for each year to control for time invariant effect in the regression model. First, we will present our baseline model result of the pooled estimation. Then robustness checking of our baseline model and in the later part of this section we will demonstrate the country-wise regression results. In all the cases, we allowed for individual heterogeneity and used robust standard error ${ }^{5}$.

\subsection{Baseline result}

Result of our baseline model of fixed effect regression, where we assumed each country's banking sector as a single representative firm, has been presented in table -3: determinants of net interest margins of banks in South Asia, 1997-2012, total sample. The first column of the table

\footnotetext{
${ }^{4}$ The Hausman test allows the null hypothesis that the individual effect and the explanatory variables are uncorrelated, rejected in all the cases.

${ }^{5}$ Confirmed by LM Heteroskedasticity test and the test statistics (p-value) are presented in the respective tables.
} 
present the list of the dependent and independent variables but the independent variables have been presented in quite classification of bank specific, industry specific and macroeconomic specific variables respectively.

Another feature of the presentation of table -3 is that there are two models- model 1 and model 2. Three columns of each of the model 1 and model 2 present the coefficient, robust standard error and t-statistics respectively.

In model 1 we included the explanatory variable -relative size of the bank but excluded in model 2. We did so to see the particular effect of this variable to determine net interest margins as the previous literature ignored the importance of this variable. We found that relative size of the bank plays an important role in determining net interest margins of banks. We see the inverse relationship between the relative size of banks and the net interest margins and support our hypothesis that the larger banks charge smaller interest margins and vice versa. In particular, a $10 \%$ rise in the value of relative size of the banks would decrease net interest margins by 50 basis points. We also have confirmed the justification of inclusion of this variable in our baseline regression model by checking the $R^{2}$. In model 2, where we excluded this variable, the $R^{2}$ is 0.2693 while in model 1 , where we included the variable of relative size of the banks, the $R^{2}$ is 0.2932 .

Non-performing loan (NPL), which also capture the so called credit risk exposure of the banking firm, found negative coefficient but statistically insignificant in our study. This result opposes the major studies in the past like Ho and Saunders (1981), Angbanzo (1997), Saunders and Schumacher (2000), Maudos and Guevara (2004), Hawtrey and Liang (2008), mostly of the developed countries. This finding is also in contrast the macroeconomic framework of Bernanke, 
Gertler and Gilchrist (BGG) (1999) where they assumed that default probabilities and default premia rise when the aggregate return to capital is lower than expected. In counter, Williams (2007), Hesse (2007) and Fungacova and Poghosyan (2011) who studied on Australian banking, Kenyan and Russian banking respectively, found credit risk is negatively related to net interest margins.

We studied the interaction term variable of NPL and Standard deviation of short term interest rate (SDint) that is NPL*SDint to see whether these two variables are jointly have any significant impact on net interest margins or not. We found NPL*SDint has insignificant relationship with net interest margins in the South Asian banking markets.

Liquid asset to total asset ratio is significant and positively related to net interest margins of banks. Economically a 10\% increase in this explanatory variable would lead to raise net interest margins by 32 basis points. This implies that the solvent banks charge higher margins exposing their financial strength in terms of their excellent liquidity position.

\section{$<$ Table-3>}

Equity to total asset ratio (E/TA) is positively related to the net interest margins of banks with statistically significant impact. We found that if the equity to total asset ratio increases by $10 \%$ then net interest margins of banks would increase by 64 basis points. As we stated in section 3.2.1 (e) that past literature has collided expectations regarding the relationship between equity to total asset ratio and the net interest margins of banks. In the mainstream banking and finance literature expect positive sign arguing that 'banks are special' and customers are willing to pay for that specialness. In the macroeconomics literature, Gertler and Kiyotaki (2011) framework argued the rise in net worth (equity) relative to the capital stock reduces the expected default 
probability so banks can charge lower margins holding other things remain constant. However, result of this paper support our hypothesis that solvent banks charge higher net interest margins.

Total loan to total deposit (TL/TD) ratio which captures the funding channel(s) of the banks for loans and advances found positive coefficient but insignificantly related to the net interest margins of banks.

Log (Loan) which also be termed as the size of the operation of banks has insignificant relationship to the net interest margins of banks according to our baseline study on South Asian banking. This outcome fails to prove our initial hypothesis that size of operation and net interest margins of banks are positively related. But South Asian banking scenario seems different from the hypothesis.

Net non interest income (the ratio of the difference between non-interest expense and noninterest revenue to total asset) found to be insignificant.

Required or regulatory reserve to total asset ratio and net interest margins of banks are positively related and the relationship is statistically significant. The result is also supportive to the baseline dealership model of net interest margins determination of Ho and Saunders (1981) and also the subsequent expansion and their studies of the model so as our initial hypothesis that everything else constant, increase in cost of reserve will cause increase in interest margins of banks. That is if the bank's cost of holding regulatory reserve increases, banks subsequently shift that cost burden to the customers. Economically speaking, a $10 \%$ rise in the required reserve ratio will increase the net interest margins by 48 basis points.

We found positive and statistically significant relationship between operating expense to total asset ratio and the net interest margins of banks in our South Asian banking studies. The baseline 
result states that a $10 \%$ increase in operating expense to total asset ratio will raise the net interest margins by $2.3 \%$. The variable covers the level of efficiency of a bank. We proved our hypothesis that efficient banks (here in our study, in terms of cost or cost efficiency) may charge lower margins or in other way, customers are paying higher to the less efficient banks in South Asia.

Operating expenses to gross income ratio or the quality of management found insignificantly related to the net interest margins of banks.

Market structure (Herfindahl index) of banking in South Asian countries and net interest margins of banks are inversely related and found statistically significant. This result disproves our initial hypothesis that higher market concentration will create scope for charging higher interest margins for banks. This divert outcomes of the studies may arise question regarding the significant differences in the market structures of the different economic background economies and their impact on determination of net interest margins for their banking market.

Finally, among the macroeconomics specific variables, we found standard deviation of short term interest rate (SDint) and the rate of inflation have no significant relationship in determining the net interest margins of banks.

Growth rate of Gross Domestic Product (GDP) and net interest margins are negatively and statistically significantly related. That is if the economy grows at $10 \%$ then we can expect a 61 basis points reduction in the net interest margins of banks. The economics of thinking so is that when GDP grows, economic expansion also becomes visible. In that expansionary economy bank can expand their business and thus will be able to charge less form their customers. 
Finally we introduced time dummies for every years of our observation period to capture the time specific effect (if any). But we found time effect is insignificant to determine the net interest margin of banks in the South Asian countries.

\subsection{Robustness check}

Table -4: robustness check for the determinants of net interest margins of banks in South Asia, 1997-2012, total sample presents the robust result of our baseline model of determinants of net interest margins. We conducted the robustness check for our baseline models by using the Concentration Ratio (CR3) as an alternative measure of Herfindahl index (HI). CR3 has been calculated as the ratio of assets of largest 3 banks to the total asset of the banking industry (Fungacova at all, 2011).

However, using CR3 as an alternative measurement of market structure, we found no change in signs and no significant change in values of the coefficients of the explanatory variables. The reported estimation results, presented in table-4, confirm that the results obtained for the baseline model remain valid.

\section{<Table-4>}

\subsection{Country-wise regression output}

We estimated the explanatory equation of the determinants of net interest margins of banks for each of the country's banking sector included in our baseline model. Our aim was to see the country variation (if any) and their impact on determining the net interest margins. Another intention to do so as our fixed effect regression model does not determine the country specific variation (if any) by using country dummies in the regression equation. 
However, the country specific regression output has been presented on table-5: country-wise regression of determinants of net interest margins, 1997-2012, total sample. From table-5, we see the coefficients of the determinants of the explanatory variables vary among countries. For example, the coefficient for the variable, relative size of the bank is statistically significant only in case of Nepal although the sign of the coefficient is negative for every country. We found positive and statistically significant coefficient for non performing loan for Bangladesh and Nepal. For Pakistan, the coefficient is negative and statistically significant. But for India, the coefficient bears negative sign but statistically insignificant.

Liquid asset to total asset ratio found significant and positively related to net interest margins of banks in Bangladesh and Pakistan but insignificant for India and Nepal.

Equity to total asset ratio found highly significant and positively related to net interest margins for Bangladesh, India and Nepal. For Pakistan, found positive coefficient but marginally insignificant.

Total loan to total deposit ratio is positively and significantly determine the net interest margins of banks in India, Nepal and Pakistan. Log (loan) plays significant and positive role in the banking market of Bangladesh and Nepal.

\section{<Table-5>}

Net non interest income is positively and significantly related to net interest margins of banks in Bangladesh and India. Whatever the margins in the banking markets of Bangladesh and India, can be attributed to this variable largely. For every 1 percent increase in net non interest income will result about $0.57 \%$ and $0.25 \%$ increase in net interest margins in Bangladesh and India 
respectively. For Nepal, the impact of net non interest income on determining interest margins of banks is negative and statistically significant. In Pakistan, this is insignificant.

Required reserve to total asset ratio is found positively related to the net interest margins but found statistically significant for Bangladesh and Pakistan.

Operating expenses to total asset ratio is highly significant and has positive impact to determine net interest margins of banks in all the countries included in our study. In Bangladesh and Nepal, lion's share of the net interest margins is determined by this variable. For every 1 percent increase in operating expense to total asset ratio, interest margins will increase by around 0.71 percent, 0.28 percent, 0.62 percent and 0.26 percent in Bangladesh, India, Nepal and Pakistan banking markets respectively.

Operating expenses to gross income ratio is significant only in case of Bangladesh and is negatively related to net interest margins of banks.

According to the country specific regression output, we see Herfindahl index i.e. the market structure is important to determine interest margins of banks in Pakistan where this variable is negatively related to the interest margins and significant at 10 percent standard error.

Among the macroeconomic specific variables, we found short term interest rate, which have been proxies by the standard deviation of short term interest rate (SDint) is significant and negatively related to net interest margins of banks in India. Rate of inflation plays significant negative role to determine interest margins of banks in Nepal. Finally, growth rate of GDP plays significant and positive role in Bangladesh but negative role in Pakistan in determining net interest margins of banks. 


\section{Conclusions and implications}

Using a comprehensive cross - country panel data set with bank-level, industry-level and macroeconomic -level explanatory variables, this paper presents the empirical results on how bank specific, industry specific and macroeconomics specific factors affect the interest margins of banks. We started from the dealership model of Ho and Saunders (1981) and later extension by other authors but followed the single stage model of margin determination and included four South Asian countries' that is Bangladesh, India, Nepal and Pakistan banking sector data covering the period of 1997-2012. Our empirical findings are consistent with our theoretical analysis.

Among the bank specific determinants, we found the liquid asset to total asset ratio, equity to total asset ratio, required reserve to total asset ratio and operating expenses to total asset ratio are positively related and the relative size of the bank is negatively related to the interest margins of banks at $1 \%$ significance level. Unfortunately our result does not support significant relationship between non-performing loan or the default risk and the interest margins.

A negative concentration effect found in the South Asian banking may be due to the high concentration of the foreign banks those charge lower interest margins. A market characterized by foreign banks has lower interest margin because of superior management or production technology (Tarus et al. 2012).

However, the macroeconomic variables like standard deviation of interest rate and the rate of inflation found insignificantly related to interest margins. But the economic growth has significant and negative relationship with bank interest margin which suggest that national economic prosperity provides sound interest margin compensation to the banks.

We conducted our panel empirical study employing both fixed effect and random effect estimations but fixed effect model performs better and generates the preferred specification. Robust standard error has 
been incorporated for the base line model, the robustness check and the country-wise regression which ensure the correct inferences from the estimation.

Regarding policy implications, we suggest the banks to take appropriate actions so that the default probability would have proper reflection in determining the interest margins. For the regulatory bodies, we recommend liberal policy actions for new entrants that could contribute to the improvement of the competitive environment in the industry in order to reduce the cost of financial intermediation to facilitate the society as a whole.

In terms of directions for future research, studies on a number of additional explanatory variables like corporate tax rates, competition among banks and other financial institutions, ownership structure, deposit insurance, information asymmetry, portfolio effect would be tested as the extension of the model. Due to limitation of data and the degrees of freedom or for the potential multicollinearty problem, we could not have fruitful insight of the literature but doing such could be apparently an interesting path for future research. 


\section{References:}

1. Abreu, M., \& Mendes, V., 2003. Do macro financial variables matter for European bank interest margins and profitability. Financial Management Association International.

2. Afanisieff, T., Lhacer, P., and Nakane, M. 2002, The determinants of bank interest spread in Brazil. Centre for Latin American Monetary Studies, Money Affairs 15 (July-December (2)), 183-207.

3. Allen L., 1988. The determinants of bank interest margins: a note. Journal of Financial and Quantitative Analysis, 23, 231-235.

4. Angbazo, L., 1997. Commercial bank net interest margins, default risk, interest rate risk and offbalance sheet banking. Journal of Banking and Finance, 21, 55-87.

5. Bank Scope, 2013. Bureau Van Dijk, New York.

6. Bank for International Settlements (BIS), 1999. Credit risk modeling: Current practices and applications, Switzerland: Basel Committee.

7. Berger, A. N., 1995a. The profit structure relationship in banking: test of market power and efficient structure hypothesis. Journal of Money, Credit and Banking, 27 (2), 404-31.

8. Berger, A.N., Udell, G.F., 1992. Some evidence on the empirical significance of credit rationing. Journal of Political Economy 100 (5), 1047-1077.

9. Bernanke, Ben S., Gertler, M., and Gilchrist, S., 1999. The financial accelerator in a quantitative business cycle framework. Handbook of Macroeconomics, Vol. 1, Elsevier Science, B.V.

10. Degryse, H., Kim, M., and Ongena, S., 2009. Microeconometrics of Banking Methods, Applications and Results, Oxford University Press

11. Dufresne, Pierre C., et. el., 2001. The determinants of credit spread changes. The Journal of Finance, Vol. 56, No. 6, December.

12. Editorial., 2013. Recent developments in financial markets and banking. Journal of Banking and Finance, 37, 5392- 5393. 
13. Focarelli, D., Panetta, F., 2003. Are merger beneficial to consumers? Evidence from the market for bank deposits. American Economic Review 93 (4), 1152-1172.

14. Fungacova, Z., Poghosyan, T., 2011. Determinants of bank interest margins in Russia: Does bank ownership matter? Economic Systems 35 (2011), 481-495.

15. Gambacorta, L., 2000. How do banks set interest rates? European Economic Review, 52 (2008), 792-819.

16. Gertler, M., Kiyotaki, N., 2011. Financial intermediation and credit policy in business cycle analysis. Handbook of Monetary Economics, Vol. 3A, ISSN 0169-7218, Elsevier B. V.

17. Gischer, H. Juttner, D.J., 2002. Global competition, fee income and interest rate margins of banks. Financial management association conference

18. Gropp, R., et. el., 2007. The dynamics of bank spreads and financial structure. European Central bank, Working paper series, No. 714/January.

19. Hawtrey, K. and Liang, H., 2008. Bank interest margins in OECD countries. North American Journal of Economics and Finance 19 (2008) 249-260.

20. Hesse, H., 2007. Financial intermediation in the pre-consolidated banking sector in Nigeria. World Bank Policy Research Working Paper 4267, Washington, DC.

21. Ho, T., Saunders, A., 1981. The determinants of bank interest margins: theory and empirical evidence. Journal of Financial and Quantitative Analysis, 16, 581-600.

22. International Financial Statistics (IFS), July, 2014. International Monetary Fund (IMF), Washington DC, 20431, USA.

23. Ivashina, V., 2004. Asymmetric information effects on loan spreads. Harvard Business School.

24. Kunt, A.D., Huizinga, H., 1999. Determinants of commercial bank interest margins and profitability: Some international evidence. The World Bank Economic Review, Vol. 13, No. 2, 379-408.

25. Lerner, E.M., 1981. Discussion. The determinants of bank interest margins: Theory and empirical evidence. Journal of Financial and Quantitative Analysis XVI (4), 601-602. 
26. McShane, W., Sharpe, G., 1985. A time series/ cross section analysis of the determinants of Australian trading bank loan/deposit interest margins: 1962- 1981. Journal of Banking \& Finance, 9, (1), p. 115-136.

27. Maudos, J., Fernandez de Guevara, J., 2004. Factors explaining the interest margin in the banking sectors of the European Union. Journal of Banking \& Finance 28, 2259-2281.

28. Nishiyama, Shin-Ichi, Okada, T., Watanabe, W., 2006. Do banks reduce lending preemptively in response to capital losses? Evidence from Japan. RIETI discussion paper series, March.

29. Saunders, A., Schumacher, L., 2000. The determinants of bank interest margins: an international study. Journal of International Money and Finance, 19 (2000), 813-832.

30. Tarus, D.K., Chekol, Y.B., Mutwol, M., 2012. Determinants of net interest margins of commercial banks in Kenya: A panel study. Procedia Economics and Finance 2 (2012) 199-208.

31. Valverde, SC., Fernandez, FR., 2007. The determinants of bank margins in European banking. Journal of Banking \& Finance 31 (2007) 2043-2063.

32. Williams, B., 2007. Factors determining net interest margins in Australia: domestic and foreign banks. Financial Markets, Institutions and Instruments 16, 145-165.

33. www.bangladesh-bank.org/ July, 2014

34. www.centralbankofindia.co.in/ July, 2014

35. www.nrb.org.np/ July, 2014

36. www.sbp.org.pk/ July, 2014

37. Xavier, F., Rochet, Jean-Charles, 2008. Microeconomics of banking, MIT, $2^{\text {nd }}$ edition. 
Figure-1: Net Interest Margins (NIMs) in South Asian Countries

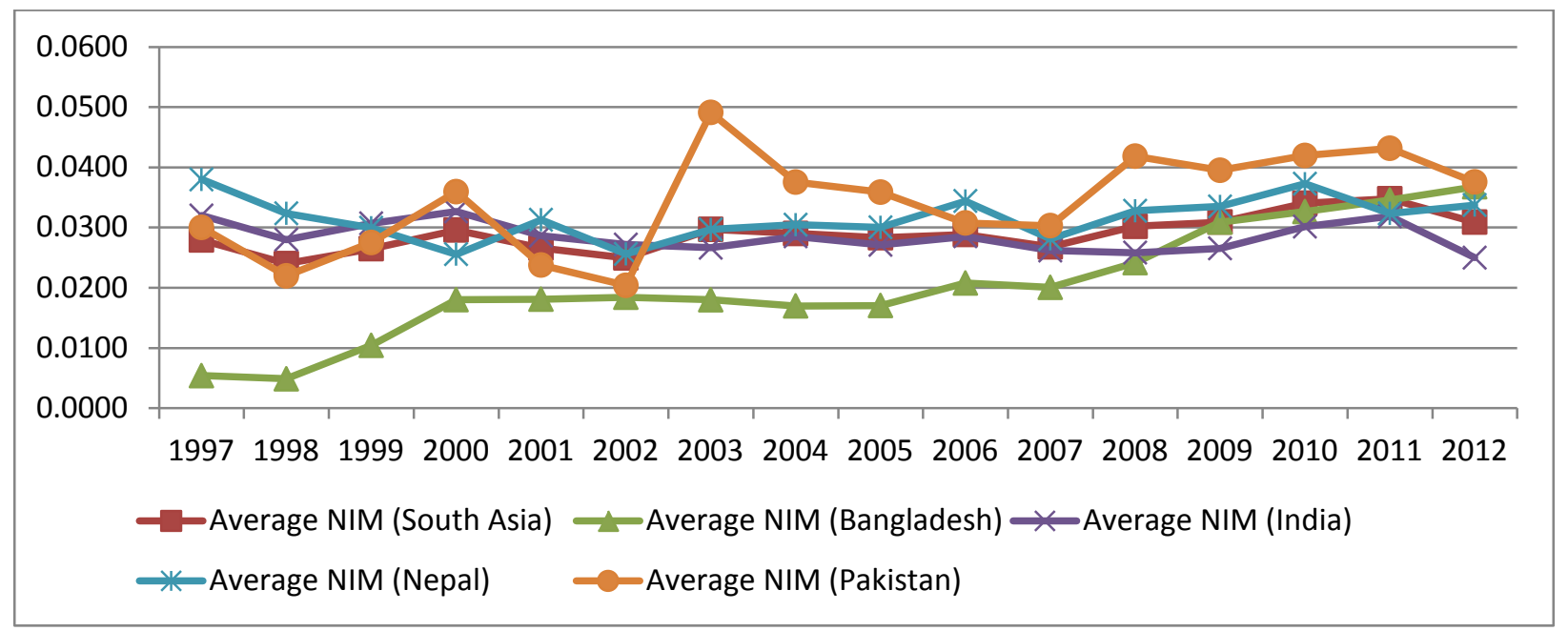

Figure-2: Standard Deviation (SD) of Net Interest Margins (NIM) in South Asian Countries

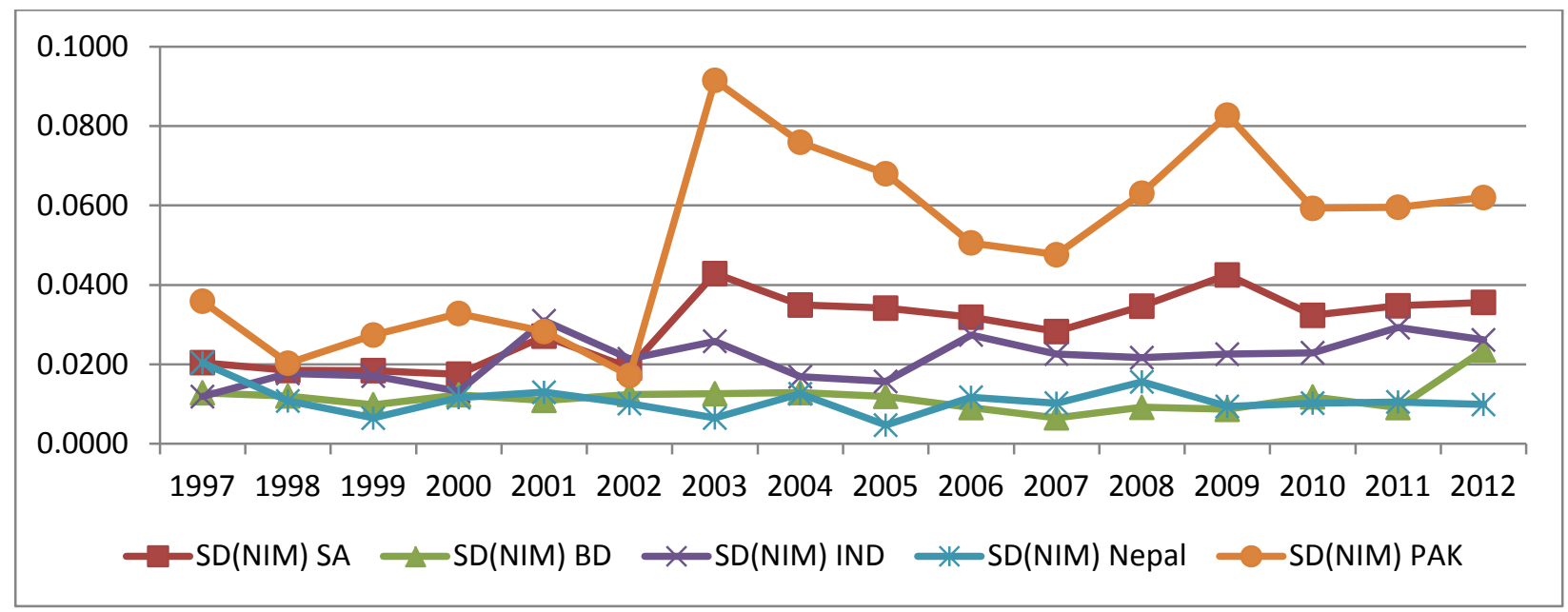


Table-1: Summary statistics of the determinants of net interest margins in South Asia from 1997-2012

\begin{tabular}{lcc}
\hline Variables & Mean & Standard Deviation \\
\hline Dependent Variable & & \\
\hline Net Interest Margins (NIM) & 0.0298 & 0.0328 \\
\hline Independent Variables & & \\
\hline Bank Specific & 0.0321 & 0.0687 \\
Relative size of the Bank & 0.0810 & 0.1045 \\
Non-performing Loan (NPL) & 0.1053 & 0.1805 \\
NPL*SDint & 0.8602 & 0.1244 \\
Liquid Asset-Total Asset Ratio & 0.1158 & 0.1336 \\
Equity - Total Asset Ratio & 3.3642 & 31.1396 \\
Total Loan-Total Deposit Ratio & 2.8274 & 0.9829 \\
Log(Loan) & 0.0066 & 0.0364 \\
Net non-interest Income & 0.0564 & 0.0563 \\
Required Reserve to Total Asset Ratio & 0.0298 & 0.0484 \\
Operating Expenses - Total Asset Ratio & 0.6771 & 0.0076 \\
Operating Expenses - Gross Income Ratio & & \\
\hline Industry Specific & 0.1398 & 0.1180 \\
Herfindahl Index & 0.5614 & 0.1804 \\
CR3 & & \\
\hline Macroeconomics Specific & 1.3558 & 1.1605 \\
Standard Deviation of Short term interest rate (SDint) & 0.0704 & 0.0347 \\
Rate of Inflation & 0.0597 & 0.0227 \\
Growth rate of GDP & & \\
\hline
\end{tabular}


Table-2: Average and Standard Deviation (SD) of Net Interest Margins (NIMs) of Banks in South Asia

\begin{tabular}{|c|c|c|c|c|c|c|c|c|c|c|}
\hline \multirow[b]{2}{*}{ Year } & \multicolumn{2}{|c|}{ South Asia } & \multicolumn{2}{|c|}{ Bangladesh } & \multicolumn{2}{|c|}{ India } & \multicolumn{2}{|c|}{ Nepal } & \multicolumn{2}{|c|}{ Pakistan } \\
\hline & $\begin{array}{l}\text { Average } \\
\text { NIM }\end{array}$ & SD(NIM) & $\begin{array}{l}\text { Average } \\
\text { NIM }\end{array}$ & SD(NIM) & $\begin{array}{l}\text { Average } \\
\text { NIM }\end{array}$ & SD(NIM) & $\begin{array}{c}\text { Average } \\
\text { NIM }\end{array}$ & SD(NIM) & $\begin{array}{l}\text { Average } \\
\text { NIM) }\end{array}$ & SD(NIM) \\
\hline 1997 & 0.0279 & 0.0204 & 0.0054 & 0.0128 & 0.0320 & 0.0119 & 0.0380 & 0.0204 & 0.0300 & 0.0359 \\
\hline 1998 & 0.0240 & 0.0185 & 0.0049 & 0.0120 & 0.0280 & 0.0177 & 0.0324 & 0.0108 & 0.0220 & 0.0203 \\
\hline 1999 & 0.0265 & 0.0184 & 0.0104 & 0.0098 & 0.0307 & 0.0171 & 0.0300 & 0.0065 & 0.0275 & 0.0274 \\
\hline 2000 & 0.0296 & 0.0175 & 0.0180 & 0.0123 & 0.0327 & 0.0132 & 0.0256 & 0.0116 & 0.0359 & 0.0328 \\
\hline 2001 & 0.0266 & 0.0271 & 0.0181 & 0.0109 & 0.0287 & 0.0310 & 0.0313 & 0.0130 & 0.0238 & 0.0283 \\
\hline 2002 & 0.0249 & 0.0191 & 0.0184 & 0.0124 & 0.0272 & 0.0214 & 0.0256 & 0.0101 & 0.0204 & 0.0172 \\
\hline 2003 & 0.0297 & 0.0428 & 0.0180 & 0.0126 & 0.0266 & 0.0258 & 0.0297 & 0.0065 & 0.0491 & 0.0915 \\
\hline 2004 & 0.0290 & 0.0349 & 0.0170 & 0.0129 & 0.0285 & 0.0169 & 0.0305 & 0.0126 & 0.0375 & 0.0759 \\
\hline 2005 & 0.0283 & 0.0342 & 0.0170 & 0.0119 & 0.0271 & 0.0157 & 0.0300 & 0.0047 & 0.0359 & 0.0680 \\
\hline 2006 & 0.0288 & 0.0319 & 0.0208 & 0.0091 & 0.0285 & 0.0274 & 0.0344 & 0.0117 & 0.0308 & 0.0506 \\
\hline 2007 & 0.0268 & 0.0283 & 0.0201 & 0.0065 & 0.0262 & 0.0226 & 0.0281 & 0.0102 & 0.0303 & 0.0476 \\
\hline 2008 & 0.0302 & 0.0346 & 0.0242 & 0.0092 & 0.0258 & 0.0217 & 0.0328 & 0.0156 & 0.0418 & 0.0631 \\
\hline 2009 & 0.0309 & 0.0425 & 0.0309 & 0.0087 & 0.0265 & 0.0226 & 0.0335 & 0.0094 & 0.0395 & 0.0827 \\
\hline 2010 & 0.0340 & 0.0323 & 0.0326 & 0.0118 & 0.0301 & 0.0229 & 0.0373 & 0.0102 & 0.0420 & 0.0593 \\
\hline 2011 & 0.0348 & 0.0347 & 0.0346 & 0.0091 & 0.0318 & 0.0292 & 0.0323 & 0.0105 & 0.0432 & 0.0596 \\
\hline 2012 & 0.0309 & 0.0356 & 0.0368 & 0.0236 & 0.0250 & 0.0261 & 0.0337 & 0.0099 & 0.0376 & 0.0620 \\
\hline
\end{tabular}


Table - 3: Determinants ${ }^{6}$ of Net Interest Margins of Banks in South Asia, 1997-2012, Total Sample

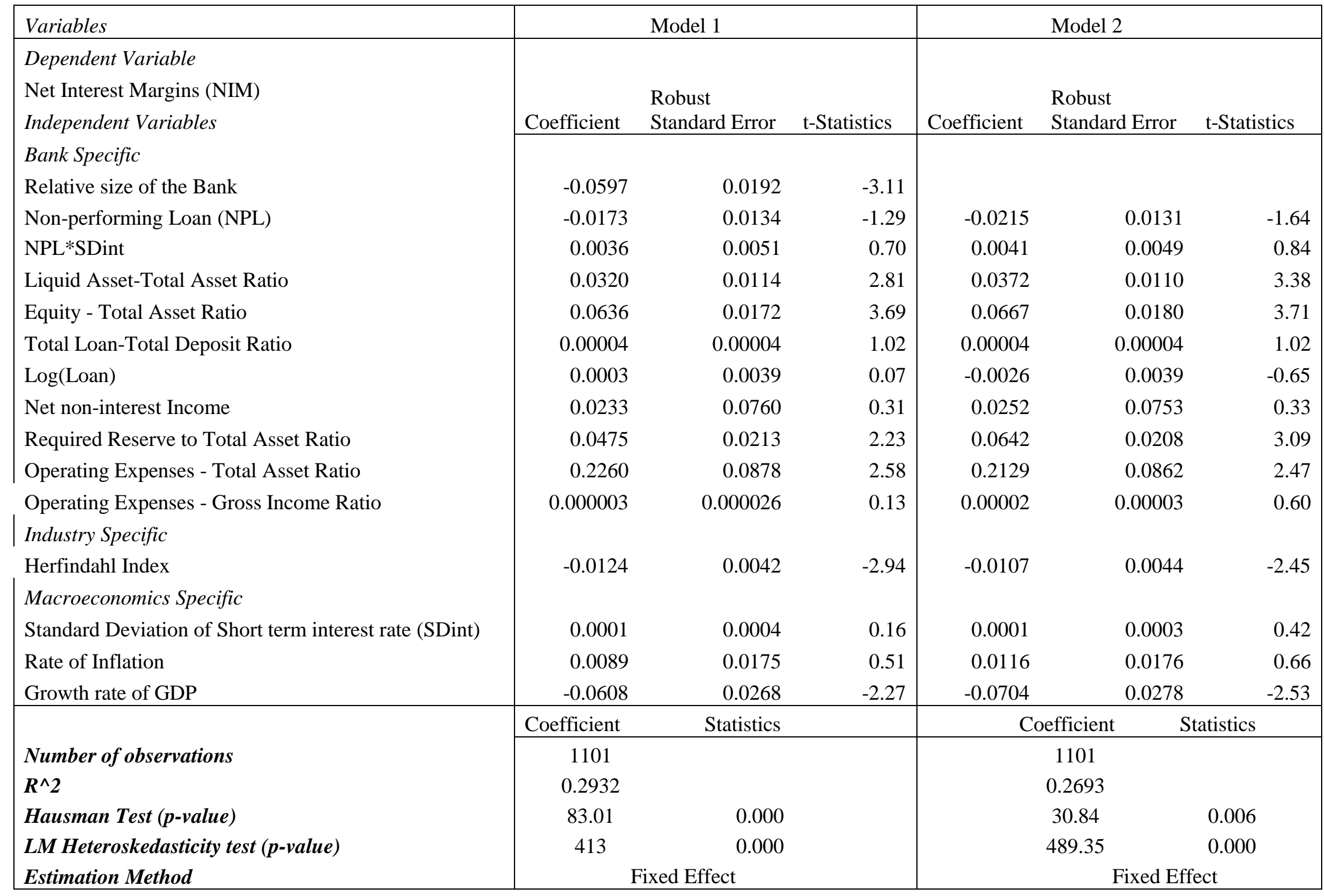

\footnotetext{
${ }^{6}$ Time dummies are included in the baseline model but the coefficients of the time dummies and the constant are not reported.
} 
Table - 4: Robustness Check for the Determinants of Net Interest Margins of Banks in South Asia, 1997-2012, Total Sample (Using CR3 as alternative of Herfindahl Index)

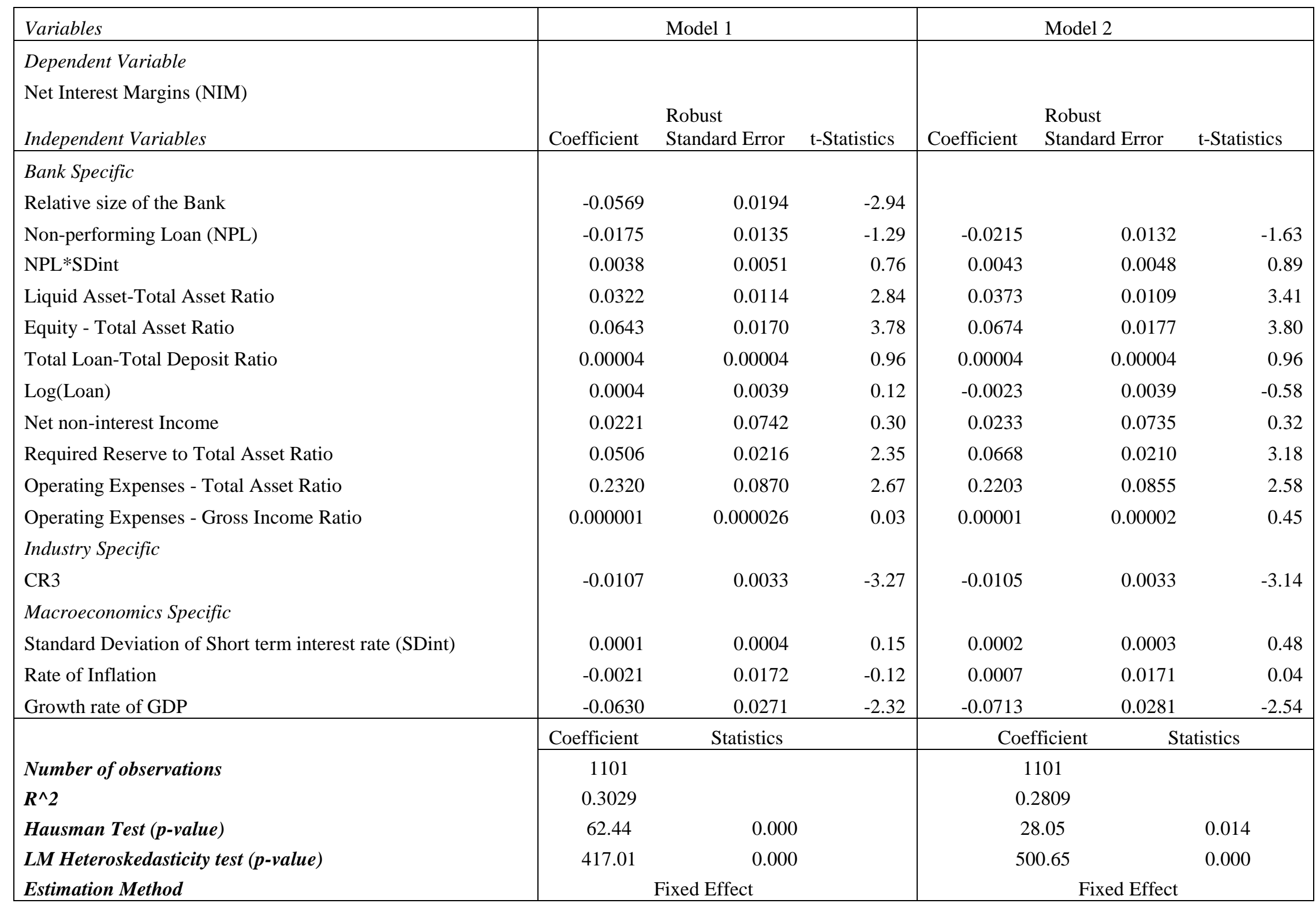


Table - 5: Country-wise Regression of Determinants of Net Interest Margins of Banks, 1997-2012, Total Sample

\begin{tabular}{|c|c|c|c|c|c|c|c|c|}
\hline Variables & \multicolumn{8}{|c|}{ Country } \\
\hline Dependent Variable & \multicolumn{2}{|c|}{ Bangladesh } & \multicolumn{2}{|c|}{ India } & \multicolumn{2}{|c|}{ Nepal } & \multicolumn{2}{|c|}{ Pakistan } \\
\hline $\begin{array}{l}\text { Net Interest Margins (NIM) } \\
\text { Independent Variables } \\
\text { Bank Specific }\end{array}$ & Coefficient & $\begin{array}{l}\mathrm{t}- \\
\text { Statistics }\end{array}$ & Coefficient & $\begin{array}{l}\mathrm{t}- \\
\text { Statistics }\end{array}$ & Coefficient & $\begin{array}{l}\mathrm{t}- \\
\text { Statistics }\end{array}$ & Coefficient & $\begin{array}{l}\mathrm{t}- \\
\text { Statistics }\end{array}$ \\
\hline Relative size of the Bank & -0.0276 & -1.31 & -0.0485 & -1.10 & -0.0628 & -2.65 & -0.0279 & -1.24 \\
\hline Liquid Asset-Total Asset Ratio & 0.1057 & 2.79 & -0.0023 & -0.27 & 0.0430 & 1.66 & 0.1320 & 3.91 \\
\hline Equity - Total Asset Ratio & 0.0999 & 2.41 & 0.0516 & 2.73 & 0.0789 & 2.15 & 0.0641 & 1.48 \\
\hline Total Loan-Total Deposit Ratio & 0.0028 & 0.24 & 0.00003 & 3.94 & 0.0084 & 2.09 & 0.0017 & 6.66 \\
\hline $\log (\operatorname{Loan})$ & 0.0155 & 2.23 & -0.0021 & -0.64 & 0.0110 & 2.01 & -0.0053 & -0.78 \\
\hline Net non-interest Income & 0.5697 & 5.16 & 0.2457 & 3.80 & -0.8017 & -3.13 & -0.0035 & -0.03 \\
\hline Herfindahl Index & 0.0003 & 0.02 & 0.0034 & 0.27 & 0.0012 & 0.37 & -0.0323 & -1.92 \\
\hline $\begin{array}{l}\text { Macroeconomics Specific } \\
\text { Standard Deviation of Short term interest } \\
\text { rate (SDint) }\end{array}$ & 0.0004 & 1.59 & -0.0010 & -2.64 & -0.0006 & -0.61 & -0.0028 & -1.43 \\
\hline Rate of Inflation & -0.0425 & -1.48 & -0.0146 & -0.85 & -0.0506 & -1.87 & 0.0233 & 0.65 \\
\hline Growth rate of GDP & 0.0759 & 2.73 & -0.0065 & -0.42 & 0.0616 & 0.63 & -0.1324 & -1.96 \\
\hline & Coefficient & Statistics & Coefficient & Statistics & Coefficient & Statistics & Coefficient & Statistics \\
\hline Number of observations & 131 & & 597 & & 123 & & 250 & \\
\hline$R^{\wedge} 2$ & 0.7945 & & 0.2950 & & 0.5678 & & 0.4854 & \\
\hline Hausman Test (p-value) & 118.21 & 0.0000 & 31.86 & 0.0104 & 37.22 & 0.0020 & 163.09 & 0.0000 \\
\hline
\end{tabular}


Appendix:

Table-A6: Empirical results regarding some key determinants of banks net interest margin in the past literature

\begin{tabular}{|c|c|c|c|c|c|c|c|}
\hline Authors & Angbanzo & $\begin{array}{l}\text { Saunders \& } \\
\text { Schumacher }\end{array}$ & $\begin{array}{l}\text { Demirguc- } \\
\text { Kunt \& } \\
\text { Huizinga } \\
\end{array}$ & $\begin{array}{l}\text { Maaudos \& } \\
\text { Guevara }\end{array}$ & Williams & Hesse & $\begin{array}{l}\text { Fungacova \& } \\
\text { Poghosyan }\end{array}$ \\
\hline Year & 1997 & 2000 & 2000 & 2004 & 2007 & 2007 & 2011 \\
\hline $\begin{array}{l}\text { Journal/Working } \\
\text { paper }\end{array}$ & JBF & JIMF & $\begin{array}{l}\text { WB Econ } \\
\text { Review }\end{array}$ & JBF & FMII & $\begin{array}{l}\text { WB Policy } \\
\text { Research } \\
\text { Paper }\end{array}$ & $\begin{array}{l}\text { Economic } \\
\text { Systems }\end{array}$ \\
\hline Market Structure & + & + & + & + & + & - & - \\
\hline $\begin{array}{l}\text { Credit Risk/Non- } \\
\text { performing loan }\end{array}$ & + & N/A & + & + & - & - & - \\
\hline Sample & USA & $\begin{array}{l}\text { Germany, } \\
\text { Spain, } \\
\text { France, UK, } \\
\text { Italy, } \\
\text { Switzerland, } \\
\text { USA }\end{array}$ & $\begin{array}{l}80 \text { countries } \\
\text { worldwide }\end{array}$ & $\begin{array}{l}\text { France, } \\
\text { Germany, } \\
\text { Italy, Spain }\end{array}$ & Australia & Nigeria & Russia \\
\hline Estimation Method & GLS & $\begin{array}{l}\text { Cross- } \\
\text { sectional } \\
\text { OLS for each } \\
\text { year }\end{array}$ & Pooled WLS & FE OLS & $\begin{array}{l}\text { Pooled } \\
\text { OLS, GLS } \\
\text { Random } \\
\text { effects } \\
\text { OLS }\end{array}$ & $\begin{array}{l}\text { Pooled } \\
\text { OLS, FE } \\
\text { OLS, } \\
\text { Median LS }\end{array}$ & FE OLS \\
\hline
\end{tabular}

Note: +, -, and? Indicate positive significant, negative significant and insignificant respectively. 
Table-A7: Correlation matrix* of the variables studied for the model of bank net interest margins determinants of South Asia

\begin{tabular}{|c|c|c|c|c|c|c|c|c|c|c|c|c|c|c|c|c|c|}
\hline Variables** & $\mathrm{npl}$ & $\mathrm{npl}$ *SDint & Ir & eta & tltd & IIn & nnii & re & oeta & oegi & share & hhi & $\mathrm{cr} 3$ & SDint & inf & gdp & _cons \\
\hline $\mathrm{npl}$ & 1.00 & & & & & & & & & & & & & & & & \\
\hline nplsdint & -0.50 & 1.00 & & & & & & & & & & & & & & & \\
\hline Ir & 0.33 & -0.07 & 1.00 & & & & & & & & & & & & & & \\
\hline eta & 0.33 & -0.01 & 0.12 & 1.00 & & & & & & & & & & & & & \\
\hline tltd & -0.02 & 0.01 & -0.01 & -0.02 & 1.00 & & & & & & & & & & & & \\
\hline IIn & 0.22 & 0.04 & -0.14 & 0.22 & -0.02 & 1.00 & & & & & & & & & & & \\
\hline nnii & 0.02 & -0.03 & -0.09 & 0.10 & 0.00 & -0.28 & 1.00 & & & & & & & & & & \\
\hline re & 0.18 & 0.01 & 0.56 & 0.13 & 0.01 & -0.05 & -0.10 & 1.00 & & & & & & & & & \\
\hline oeta & -0.08 & 0.04 & 0.11 & -0.08 & -0.01 & 0.28 & -0.66 & 0.06 & 1.00 & & & & & & & & \\
\hline oegi & -0.05 & 0.02 & -0.05 & 0.00 & 0.00 & -0.01 & 0.04 & -0.03 & -0.05 & 1.00 & & & & & & & \\
\hline share & -0.05 & -0.05 & 0.05 & 0.19 & 0.00 & 0.00 & -0.03 & 0.19 & -0.05 & 0.03 & 1.00 & & & & & & \\
\hline hhi & -0.01 & -0.03 & -0.07 & 0.08 & -0.01 & 0.16 & -0.02 & -0.06 & 0.01 & -0.02 & 0.03 & 1.00 & & & & & \\
\hline $\mathrm{cr} 3$ & -0.02 & 0.05 & 0.03 & -0.09 & 0.01 & -0.13 & 0.06 & 0.02 & -0.07 & 0.05 & 0.03 & -0.77 & 1.00 & & & & \\
\hline sdint & 0.33 & -0.60 & 0.09 & -0.06 & -0.02 & -0.05 & 0.05 & -0.10 & -0.06 & -0.01 & 0.04 & -0.15 & 0.09 & 1.00 & & & \\
\hline inf & 0.03 & -0.01 & 0.18 & -0.22 & 0.00 & -0.56 & 0.07 & 0.12 & -0.10 & 0.00 & 0.15 & -0.19 & 0.29 & -0.01 & 1.00 & & \\
\hline gdp & 0.08 & 0.12 & 0.00 & 0.07 & -0.05 & 0.02 & 0.04 & -0.08 & 0.02 & 0.06 & -0.06 & 0.14 & -0.21 & -0.11 & -0.03 & 1.00 & \\
\hline _cons & -0.46 & 0.05 & -0.87 & -0.28 & 0.01 & -0.29 & 0.21 & -0.57 & -0.27 & 0.03 & -0.12 & 0.08 & -0.11 & -0.07 & -0.04 & -0.07 & 1.00 \\
\hline
\end{tabular}

*Output of Stata

** Refer to the table -1 of summary statistics for elaboration of the names of the variables 